\title{
Antiproliferative effects of the CDK6 inhibitor PD0332991 and its effect on signaling networks in gastric cancer cells
}

\author{
DAGUANG WANG ${ }^{1 *}$, YABIN SUN $^{2 *}$, WEI LI ${ }^{1}$, FEI YE $^{3}$, YANG ZHANG $^{1}$, \\ YUCHEN GUO $^{1}$, DAVID Y. ZHANG ${ }^{3}$ and JIAN SUO ${ }^{1}$
}

Departments of ${ }^{1}$ Gastric and Colorectal Surgery and ${ }^{2}$ Ophthalmology, The First Hospital, Jilin University, Changchun, Jilin 130021, P.R. China; ${ }^{3}$ Department of Pathology, Icahn School of Medicine at Mount Sinai, New York, NY 10029, USA

Received June 10, 2016; Accepted December 20, 2017

DOI: $10.3892 / \mathrm{ijmm} .2018 .3460$

\begin{abstract}
PD0332991 (palbociclib/Ibrance ${ }^{\circledR}$ ) is a cyclin-dependent kinase (CDK)4/6 inhibitor that has recently been approved for the treatment of estrogen receptor-positive advanced breast cancer. The present study investigated the antiproliferative effects of PD0332991 on gastric cancer (GC) cells and the underlying molecular mechanisms. The activity of PD0332991 was tested in several GC cell lines, including AGS, KATO-III, NCI-N87 and HS746T. Growth inhibitory activity of PD0332991, alone or in combination with fluorouracil (5-FU), was measured by MTT assay. The effects of PD0332991 on cell cycle progression were analyzed by flow cytometry and western blotting. Protein pathway array and Ingenuity Pathway Analysis were used to identify signaling pathways that may mediate the antiproliferative effects of PD0332991. PD0332991 inhibited proliferation in a dose-dependent manner and enhanced the activity of 5-FU in all GC cell lines tested. Cells treated with PD0332991 exhibited cell cycle arrest in $\mathrm{G}_{1}$ phase of the cell cycle, whereas the number of cells in $\mathrm{G}_{2} / \mathrm{M}$ phase was decreased. PD0332991 also inhibited CDK6-specific phosphorylation of retinoblastoma on Ser780, reduced the expression of cyclin D1, and induced expression of p53 and p27. Furthermore, 31 proteins were identified, the expression of which was significantly altered following treatment with PD0332991 in at least three cell lines. Pathway analysis indicated that the altered proteins were frequently associated with cell death, cell cycle and the molecular mechanism of cancer. The results of the present study indicated that PD0332991 may inhibit
\end{abstract}

Correspondence to: Professor Jian Suo, Department of Gastric and Colorectal Surgery, The First Hospital, Jilin University, 71 Xin Min Street, Changchun, Jilin 130021, P.R. China

E-mail: suojian42@gmail.com

Professor David Y. Zhang, Department of Pathology, Icahn School of Medicine at Mount Sinai, 1428 Madison Avenue, New York, NY 10029, USA

E-mail: david.zhang@mssm.edu

*Contributed equally

Key words: PD0332991, gastric cancer, cyclin-dependent kinase 6, ingenuity pathway analysis cell proliferation via modulation of the cell cycle, and may affect numerous oncogenic signaling pathways. Therefore, PD0332991 may be considered effective for the treatment of GC.

\section{Introduction}

Although the incidence of gastric cancer (GC) is declining, it remains the second most common cause of cancer-associated mortality worldwide (1-3). Dysregulation of numerous oncogenic signaling pathways, including E2F, K-RAS, p53 and Wnt/ $\beta$-catenin, occurs frequently in GC (4-7), thus suggesting that GC is a molecularly heterogeneous disease. Non-resectable or metastatic GC is associated with poor prognosis, and systemic chemotherapeutic approaches provide minimal benefit $(8,9)$. Therefore, there is a significant need to develop novel therapeutic approaches for the systemic therapy of this disease.

Cancer is a disease associated with dysregulated proliferation; therefore, compounds that induce cell cycle are promising candidates for the treatment and prevention of malignancy. Progression through the cell cycle is driven by cyclin-dependent kinases (CDKs) in cooperation with cyclins, which can be specifically inhibited by CDK inhibitors (10). Previous studies have detected aberrant coactivation of CDK4-cyclin D1 or CDK4/CDK6-cyclin D2 in GC (11-13).

PD0332991 (also known as palbociclib and Ibrance ${ }^{\circledR}$ ) is an orally available small molecule that potently and specifically inhibits CDK4/6 in a reversible manner $(4,10,14)$. It has emerged as a promising agent for cell cycle-based therapy, due to its ability to rapidly and specifically inhibit CDK4 and CDK6 activity. In breast cancer, PD0332991 exhibited marked effects and was recently approved by the US Food and Drug Administration (FDA) to treat advanced breast cancer (15-17). Its effects have also been detected in other tumor types, including primary human multiple myeloma cells $(5,10)$, solid tumor cell lines (4), mantle cell lymphoma and acute myeloid leukemia cells $(7,10,18)$. However, its effects on GC remain to be determined.

The present study investigated whether PD0332991 exerts anticancer activity in GC cells and the underlying molecular mechanisms. The results indicated that PD0332991 could effectively inhibit proliferation in all tested GC lines. Furthermore, according to the results of a protein pathway array (PPA), several unknown downstream targets of PD0332991 were identified in GC. 


\section{Materials and methods}

Chemicals and drugs. PD0332991 was obtained from Selleck Chemicals (Houston, TX,USA). A $10 \mu \mathrm{M}$ solution was prepared in $100 \%$ dimethyl sulfoxide (DMSO), stored in small aliquots at $-20^{\circ} \mathrm{C}$ and was diluted as required in cell culture medium. Fluorouracil (5-FU) was obtained from Sigma-Aldrich (Merck KGaA, Darmstadt, Germany), dissolved in $100 \%$ DMSO to $50 \mathrm{mM}$, and stored in small aliquots at $-20^{\circ} \mathrm{C}$ and was then diluted as required in cell culture medium.

Cell lines and cell culture. Human GC cell lines AGS, KATO-III, NCI-N87, and HS746T were obtained from Professor Goutham at Genetics and Genomic Sciences of Icahn School of Medicine at Mount Sinai (New York, NY, USA). AGS cells (gastric adenocarcinoma) were cultured in F-12K medium (Sigma-Aldrich; Merck KGaA) supplemented with $10 \%$ fetal bovine serum (FBS; Gibco, Grand Island, NY, USA). KATO-III cells (signet ring cell carcinoma) were cultured in Iscove's modified Dulbecco's medium (Lonza BioWhittaker, Verviers, Belgium) supplemented with 20\% FBS. NCI-N87 cells (gastric carcinoma) were cultured in RPMI-1640 medium (Corning Cellgro, Manassas, VA, USA) supplemented with 10\% FBS (Gibco). HS746T (gastric carcinoma) were cultured in Dulbecco's modified Eagle's medium (Gibco) supplemented with 10\% FBS (Gibco). All media were also supplemented with $100 \mathrm{U} / \mathrm{ml}$ penicillin and $100 \mu \mathrm{g} / \mathrm{ml}$ streptomycin. All cell lines were cultured at $37^{\circ} \mathrm{C}$ in a humidified incubator containing $5 \% \mathrm{CO}_{2}$.

Cell viability assay. Cell viability of GC cells was monitored using the MTT assay (Sigma-Aldrich). Approximately $5 \times 10^{3}$ cells were seeded in each well of a 96-well plate and were incubated for $24 \mathrm{~h}$ at $37^{\circ} \mathrm{C}$. Cells were left untreated, or were treated with various concentrations of PD0332991 or 5-FU for $72 \mathrm{~h}$ at $37^{\circ} \mathrm{C}$. Subsequently, $10 \mu \mathrm{l}$ MTT $(5 \mathrm{mg} / \mathrm{ml})$ was added to each well and the cells were incubated for an additional $3 \mathrm{~h}$, after which the supernatant was discarded. Finally, $100 \mu \mathrm{l}$ DMSO was added to the wells to dissolve the precipitate. Optical density was measured at a wavelength of $570 \mathrm{~nm}$ using an ELx800 (BioTek Instruments, Inc., Winooski, VT, USA).

Flow cytometric analysis. Cells were treated with PD0332991 in a dose-dependent manner for $72 \mathrm{~h}$. The cells were then washed, centrifuged at $1,000 \mathrm{rpm}$ for $10 \mathrm{~min}$, fixed with cold $70 \%$ ethanol for $\geq 30 \mathrm{~min}$, and incubated with $100 \mu \mathrm{g} / \mathrm{ml}$ RNase A and $50 \mu \mathrm{g} / \mathrm{ml}$ propidium iodide at room temperature for $30 \mathrm{~min}$. Samples were immediately analyzed by flow cytometry (BD Biosciences, San Jose, CA, USA) and cell cycle phase distribution was determined using CellQuest Pro software version 5.1 (BD Biosciences, Franklin Lakes, NJ, USA).

Western blotting. Cells were lysed using $1 \mathrm{X}$ cell lysis buffer (Cell Signaling Technology, Inc., Danvers, MA, USA) containing $20 \mathrm{mM}$ Tris- $\mathrm{HCl}$ (pH 7.5), $150 \mathrm{mM} \mathrm{NaCl}, 1$ mM EDTA-Na ${ }_{2}$, $1 \mathrm{mM}$ EGTA, $1 \%$ Triton, $2.5 \mathrm{mM}$ sodium pyrophosphate, $1 \mathrm{mM}$ $\beta$-glycerophosphate, $1 \mathrm{mM} \mathrm{Na}_{3} \mathrm{VO}_{4}$ and $1 \mu \mathrm{g} / \mathrm{ml}$ leupeptin in the presence of $1 \mathrm{X}$ Protease Inhibitor Cocktail and 1X Phosphatase Inhibitor Cocktail (both from Roche Applied Science, Madison, WI, USA). Protein concentration was determined using the Pierce Bicinchoninic Acid (BCA) Protein Assay kit (Pierce;
Thermo Fisher Scientific, Inc., Waltham, MA, USA). Equal amounts of cell lysate $(20 \mu \mathrm{l}, 1 \mu \mathrm{g} / \mu \mathrm{l})$ were then subjected to $10 \%$ SDS-PAGE under reducing conditions. Prior to loading onto the gel, all lysates were boiled for $5 \mathrm{~min}$ and immediately cooled on ice. The proteins were then transferred onto Immobilon-P membranes (EMD Millipore, Billerica, MA, USA) previously soaked in methanol and transfer buffer using the Trans-Blot SD semi-dry transfer cell (Bio-Rad Laboratories, Inc., Hercules, CA, USA). Following completion of the transfer process, the membranes were allowed to dry, soaked in methanol, and incubated with blocking buffer [5\% dry non-fat milk in $1 \mathrm{X}$ TBS- $0.1 \%$ Tween-20 (TBST)] for $1 \mathrm{~h}$ at room temperature. Membranes were then incubated with primary antibodies against phosphorylated (p)-retinoblastoma (Rb) (Ser780) (1:1,000; \#9307; Cell Signaling Technology, Inc.), CDK6 (1:1,000 sc-177; Santa Cruz Biotechnology, Inc., Dallas, TX, USA), Cyclin D1 (1:1,000; sc-718; Santa Cruz Biotechnology, Inc.), P53 (1:1,000; sc-126; Santa Cruz Biotechnology, Inc.), P27 (1:1,000; sc-528; Santa Cruz Biotechnology, Inc.) and $\beta$-actin $(1: 10,000$; \#A5316; Sigma-Aldrich; Merck KGaA), overnight at $4^{\circ} \mathrm{C}$. The membranes were washed with $1 \mathrm{X}$ TBS and $1 \mathrm{X}$ TBST, and were incubated with secondary anti-rabbit (\#1705046) or anti-mouse (\#1705047) antibodies conjugated with horseradish peroxidase (HRP) (1:10,000; Bio-Rad Laboratories, Inc.) for $1 \mathrm{~h}$ at room temperature. The membrane was developed using a chemiluminescence substrate (Immun-Star ${ }^{\mathrm{TM}}$ HRP Peroxide Buffer/Immun-Star ${ }^{\mathrm{TM}}$ HRP Luminol Enhancer; Bio-Rad Laboratories, Inc.), and chemiluminescent signals were captured using the ChemiDoc XRS system (Bio-Rad Laboratories, Inc.). The signal intensity of each protein was determined by densitometric scanning (Quantity One software package version 4.6.2; Bio-Rad Laboratories, Inc.).

PPA. Cells were treated with PD0332991 at $75 \%$ inhibitory concentration $\left(\mathrm{IC}_{75}\right)$ for $48 \mathrm{~h}$. Total cellular proteins were extracted from cells using cell lysis buffer (Cell Signaling Technology, Inc.) containing $20 \mathrm{mM}$ Tris- $\mathrm{HCl}$ (pH 7.5), $150 \mathrm{mM} \mathrm{NaCl}, 1 \mathrm{mM}$ EDTA-Na $a_{2}, 1 \mathrm{mM}$ EGTA, $1 \%$ Triton, $2.5 \mathrm{mM}$ sodium pyrophosphate, $1 \mathrm{mM} \beta$-glycerophosphate, $1 \mathrm{mM} \mathrm{Na}_{3} \mathrm{VO}_{4}$ and $1 \mu \mathrm{g} / \mathrm{ml}$ leupeptin in the presence of $1 \mathrm{X}$ Proteinase Inhibitor Cocktail and 1X Phosphatase Inhibitor Cocktail (both from Roche Applied Science). The cell lysates were sonicated twice for $15 \mathrm{sec}$, and centrifuged at $18,000 \mathrm{xg}$ for $30 \mathrm{~min}$ at $4^{\circ} \mathrm{C}$. The protein concentration was determined using the BCA Protein Assay kit (Pierce; Thermo Fisher Scientific, Inc.). Isolated proteins were separated by $10 \%$ SDS-PAGE. Cell extract containing $300 \mu \mathrm{g}$ protein was loaded into one well across the entire width of the gel. After running the gel, the proteins were electrophoretically transferred to a nitrocellulose membrane. Subsequently, the membrane was blocked for $1 \mathrm{~h}$ with $5 \%$ milk or $3 \%$ bovine serum albumin (BSA; Thermo Fisher Scientific, Inc.)

at room temperature. The membrane was then clamped with a western blotting manifold in order to isolate 20 channels across the membrane (Bio-Rad Laboratories, Inc.). Two or three primary antibodies were added to each channel and allowed to bind to proteins overnight at $4^{\circ} \mathrm{C}$. Different sets of antibodies were used for each membrane (Table I). The blot was washed and hybridized for 45 min with horseradish peroxidase-conjugated secondary antibodies [1:10,000; ant-rabbit (\#1705046) 
Table I. Antibodies included in the protein pathway array analysis.

Antibodies specific for phosphorylation

p-PKC $\alpha(\operatorname{Ser657),p-PDK1(Ser241),p-PKC\alpha /\beta II(Thr638/641),p-p53(Ser392),p-AKT(Ser473),p-PTEN(Ser380),p-Rb(Ser780),~}$ p- $\beta$-catenin(Ser33/37/Thr41), p-c-Jun (Ser73), p-Stat3 (Ser727), p-ERK (Thr202/Tyr204), p-GSK-3 $\alpha / \beta$ (Ser21/9), p-p70 S6 kinase (Thr389), p-eIF4B (Ser422), p-HGF R/c-MET (Y1234/Y1235), p-Smad (Ser463/465), p-ERK5 (Thr218/Tyr220), p-p90RSK (Ser380), p-CREB (Ser133), p-CDC2 (Tyr15), p-PKCס (Thr505), p-FAK (Tyr397), p-Rb (Ser807/811), p-p38 (Thr180/Tyr182)

Antibodies for signal transduction proteins

FAS (C-20), FOXM1 (H-92), Era (HC-20), Syk (LR), MetRS, Twist (H-81), Lyn, KLF6, CaMKKa, SK3 (H-45), Stat1 (42H3), cyclin B1, cyclin D1, Cdk6, CDC25B, cyclin E, CDK2, p27, TDP1 (H-300), Cdk4, HER2 (ErbB2), 14-3-3ß, cPKC $\alpha$, ERK/EGFR, SLUG (H-140), Cdc25C, Hsp90, CHK1, MDM2, CDC2 p34, E2F-1, PCNA, p63, p38, Rap 1 (121), $\beta$-catenin, Akt, HCAM (H-300), XIAP, Bcl-2, patched (H-267), HIF-1 $\alpha$, HIF-2 $\alpha$, TTF-1, p53, Notch4 (L5C5), PTEN, SRC-1, Eg5 (H-300), HIF-3 $\alpha$, Bax, N-cadherin, TNF- $\alpha$, cdc42, eIF4B, Vimentin, OPN, Survivin, E-cadherin, TGF- $\beta$, Erb (H-150), p27, WT1,

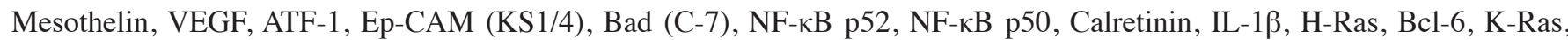
$\alpha$-tubulin, NF-кB p65, CREB, BID (C-20), Maspin (C-20), DRG1 (C-20), Factor XIII B (I-20), IGFBP5 (T-17), HCAM (DF1485), ICAM-1, Estrogen Receptor $\alpha$ (62A3), c-Flip, PSM (k1H7), Rab 7 (H-50), VCAM-1 (HAE-2z), FGF-8 (H-181), NEP(CD 10), Bcl-xL (54H6), Endoglin (H-300), Bak (G-23), TFIIH p89 (S-19), Nkx-3.1 (M-96), RIP (D94C12), NM23, c-IAP2 (H-85), Epo (H-162), uPA, PDEF (H-250), Stat3, ERCC1 (FL-297), uPAR, KAI1, L-selectin (H-149), PSCA, E-selectin

All phosphorylation state-specific antibodies were obtained from Cell Signaling Technology, Inc., with the exception of p-HGFR/c-Met (Y1234/Y1235) and p-HGFR/c-Met (Y1003), which were purchased from R\&D Systems, Inc. (Minneapolis, MN, USA). All non-phosphorylated antibodies were obtained from Santa Cruz Biotechnology, Inc., with the exception of the following antibodies: i) ERK, AKT, $\beta$-catenin, Notch4, CREB, eIF4B, NF-кB p52, NF-кB p50, and Stat1, which were obtained from Cell Signaling Technology, Inc.; ii) XIAP, which was obtained from BD Biosciences; and iii) TGF- $\beta$, which was obtained from R\&D Systems, Inc. The dilution of the antibodies was 1:1,000, except for p-PKC $\alpha$ (Ser657; 1:500), p27 (1:500), XIAP (1:250), K-Ras (1:200), factor XIII B (1:250), endoglin (1:200), Bak (1:200) and L-selectin (1:200).

and anti mouse (\#1705047); Bio-Rad Laboratories, Inc.] at room temperature. The membranes were washed and chemiluminescence signals were captured using the ChemiDoc XRS system (Bio-Rad Laboratories, Inc.). Differences in protein level were estimated by densitometric scanning (Quantity One software package version 4.6.2; Bio-Rad Laboratories, Inc.) and were normalized using internal standards.

Statistical analysis. All experiments were biologically repeated three times. PPA was performed in duplicate. Data are expressed as the means \pm SD. Statistical comparisons of results were made using one-way analysis of variance by SPSS 17.0. $\mathrm{P}<0.05$ was considered to indicate a statistically significant difference. The human pathway lists from PPA data determined by the 'Ingenuity System Database' were selected (Qiagen, Inc., Valencia, CA, USA). Ingenuity Pathway Analysis (IPA) is a system that transforms large data sets into a group of relevant networks containing direct and indirect relationships between genes based on known interactions in the literature. The gene names of differentially expressed proteins were input into the IPA system. According to IPA, a score of 3 indicates that there is a 1/1,000 chance that the focus genes are in a network due to random chance; therefore, scores $>3$ have a $99.9 \%$ confidence of not being generated by random chance. This score was used as the cut-off for identifying gene networks that were significantly affected by the drug. Differentially expressed proteins were mapped to canonical pathways, functions and tested by the Fisher's exact test. Significance threshold was set at $\mathrm{P}=0.001$.

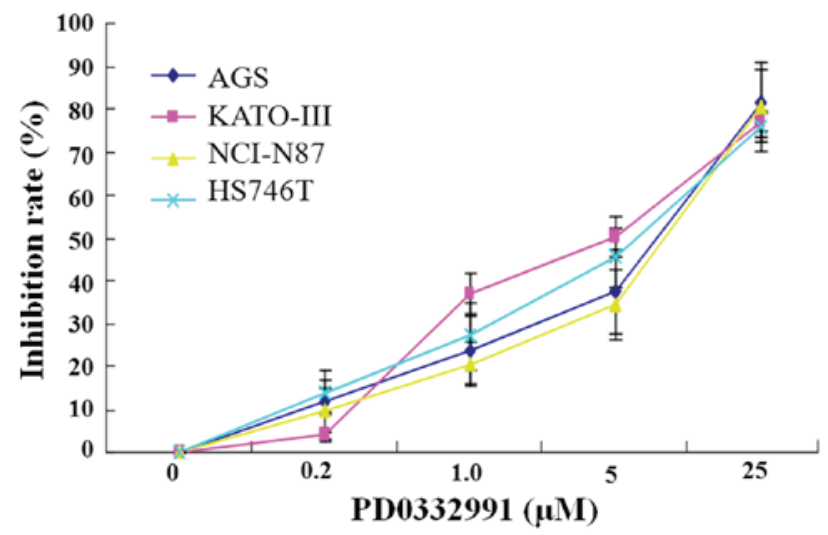

Figure 1. Inhibitory effects of PD0332991 on cell proliferation in AGS, KATO-III, NCI-N87 and HS746T cells. Cells were seeded into 96-well plates and were treated with PD0332991 in a dose-dependent manner for $72 \mathrm{~h}$. Cell number was then determined and compared with untreated cells.

\section{Results}

PD0332991 inhibits growth of GC cells. To determine whether PD0332991 inhibits proliferation of GC cells, AGS, KATO-III, NCI-N87 and HS756T cells were treated with varying concentrations of PD0332991 (0.2-25 $\mu \mathrm{m})$ for $72 \mathrm{~h}$ and cell proliferation was measured by the MTT assay. The inhibitory rate of PD0332991 was determined as a percentage of viable cells in treated cultures compared with control cells. As shown in Fig. 1, PD0332991 inhibited proliferation of GC cells 


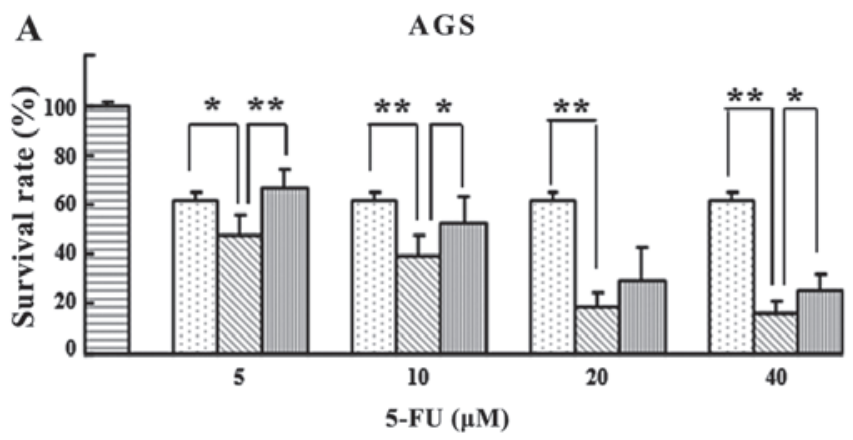

C

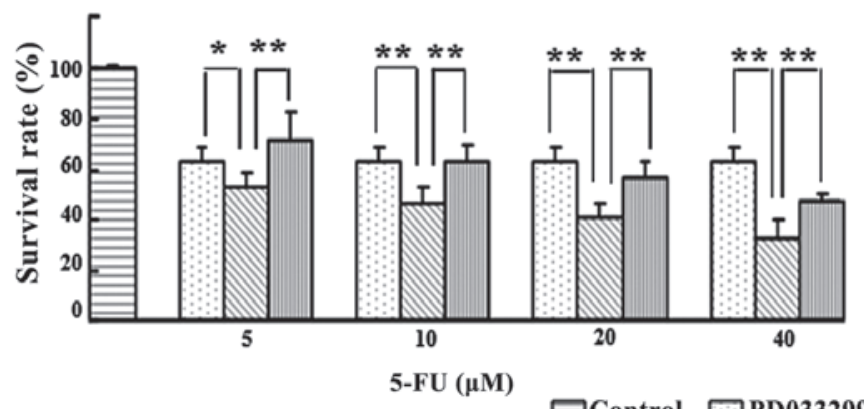

B

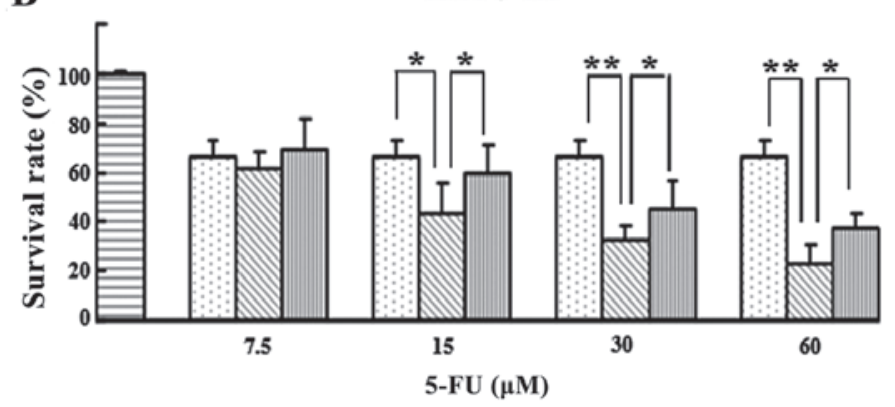

D

HS746 T

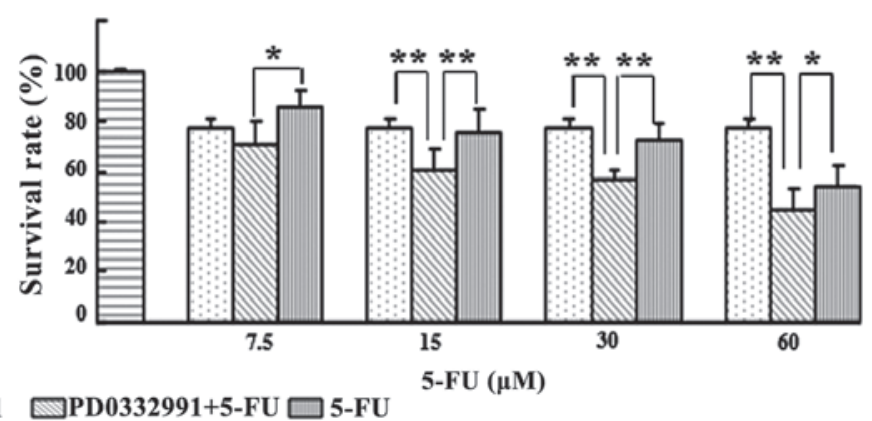

Figure 2. Inhibitory effects of PD0332991 and 5-FU on cell proliferation in (A) AGS, (B) KATO-III, (C) NCI-N87 and (D) HS746T cells. Cells were seeded into 96-well plates and were treated with various doses of 5-FU, or with a combination of 5-FU and PD0332991. Cell number was determined and compared with untreated cells. 5-FU, fluorouracil.

in a dose-dependent manner, with a $50 \%$ inhibitory concentration $\left(\mathrm{IC}_{50}\right)$ value of $12 \mu \mathrm{M}$ in AGS cells, 5.0 $\mu \mathrm{M}$ in KATO-III cells, $13 \mu \mathrm{M}$ in NCI-N87 cells and $11 \mu \mathrm{M}$ in HS756T cells. The $\mathrm{IC}_{50}$ value was calculated from nine independent experiments. These results indicated that PD0332991 may inhibit the growth of GC cells.

PD0332991 increases the efficiency of 5-FU in GC cells. The present study demonstrated that proliferation of AGS, KATO-III, NCI-N87 and HS746T cells was significantly reduced by PD0332991 (Fig. 1). Therefore, the present study subsequently examined whether PD0332991 affects the response of GC cells to 5-FU. Cells were treated with increasing concentrations of 5-FU (5-60 $\mu \mathrm{M})$, alone or in combination with PD0332991 (at a concentration lower than $\left.\mathrm{IC}_{50}\right)$. The results demonstrated that PD0332991 enhanced the proliferation-inhibiting effects of 5-FU (Fig. 2). As presented in Fig. 3, the $\mathrm{IC}_{50}$ value of 5-FU was significantly decreased by PD0332991 in all GC cell lines. The inhibitory effects of the combination of PD0332991 and 5-FU were stronger than the expected additive effects in all cell lines, thus suggesting that PD0332991 and 5-FU synergize. Taken together, these findings indicated that PD0332991 not only inhibits proliferation of GC cells, but also enhances the cytotoxic effects of 5-FU, a common chemotherapeutic drug used to treat GC.

PD0332991 induces $G_{1}$ cell cycle arrest in GC cells. To understand the molecular mechanism underlying the effects of PD0332991, the present study analyzed the effects of PD0332991 on cell cycle progression in four GC cell lines. AGS, KATO-III, NCI-N87 and HS746T cells were treated with 1.0 or $5.0 \mu \mathrm{M}$ PD0332991 for $72 \mathrm{~h}$. The results demonstrated that PD0332991 triggered arrest of cells in $\mathrm{G}_{1}$ phase, with a concurrent decrease of cells in $\mathrm{G}_{2} / \mathrm{M}$ phase (Fig. 4, Table II). Upon treatment with PD0332991 the percentage of cells in $\mathrm{G}_{1}$ phase increased from 53.03 to $79.2 \%(1 \mu \mathrm{M})$ and to $82.25 \%(5 \mu \mathrm{M})$ in HS746T cells. PD0332991 increased $\mathrm{G}_{1}$ cells from 63.35 to $68.48 \%(1 \mu \mathrm{M})$ and to $75.15 \%(5 \mu \mathrm{M})$ in AGS cells. In KATO-III cells, PD0332991 increased the percentage of cells in $\mathrm{G}_{1}$ phase from 60.32 to $72.72 \%(1 \mu \mathrm{M})$ and to $82.74 \%(5.0 \mu \mathrm{M})$. In NCI-N87 cells, the percentage of cells in $\mathrm{G}_{1}$ phase was increased from 65.60 to $75.60 \%$ in cells treated with $1.0 \mu \mathrm{M}$ PD0332991, and to $74.65 \%$ in cells treated with $5.0 \mu \mathrm{M}$. The percentage of cells in S phase was decreased by PD0332991 in all cell lines (Fig. 4, Table II). These results suggested that the antiproliferative effects of PD0332991 may be due to cell cycle arrest.

PD0332991 inhibits Rb phosphorylation in GC cells on CDK6-specific sites. The present study demonstrated that PD0332991 induces $\mathrm{G}_{1}$ arrest in GC cell lines (Fig. 4). PD0332991 is a potent and highly selective inhibitor of CDK6/4 kinase activity; the only known substrates for CDK4/6 are the $\mathrm{Rb}$ family proteins. Of the 16 known phosphorylation sites on $\mathrm{Rb}$, two are specifically phosphorylated by CDK4/6: Ser780 and Ser795. Therefore, phosphorylation status of $\mathrm{Rb}$ at these specific sites represents an appropriate biomarker for the activity of CDK4/6 in tumor cells and tissues. To determine the inhibitory effects of PD0332991 on CDK6 in GC cells, the four GC cell lines were treated with PD0332991 for $48 \mathrm{~h}$. The results demonstrated that PD0332991 did not alter the expression levels of CDK6; however, it did significantly inhibit phosphory- 
Table II. Results of cell cycle analysis in cell lines following treatment with PD0332991, as determined using flow cytometry.

\begin{tabular}{|c|c|c|c|c|c|}
\hline \multirow[b]{2}{*}{ Cell line } & \multirow[b]{2}{*}{ PD0332991 $(\mu \mathrm{M})$} & \multicolumn{4}{|c|}{ Cell cycle phase } \\
\hline & & $\operatorname{SubG}_{1}(\%)$ & $\mathrm{G}_{0} / \mathrm{G}_{1}(\%)$ & $\mathrm{S}(\%)$ & $\mathrm{G}_{2} / \mathrm{M}(\%)$ \\
\hline \multirow[t]{3}{*}{ HS746T } & 0 & $1.47 \pm 0.36$ & $53.03 \pm 1.72$ & $15.33 \pm 1.09$ & $30.61 \pm 3.05$ \\
\hline & 1.0 & $1.69 \pm 0.37$ & $79.2 \pm 0.01^{\mathrm{a}}$ & $8.76 \pm 0.10$ & $10.70 \pm 0.27$ \\
\hline & 5.0 & $1.66 \pm 0.44$ & $82.25 \pm 0.15^{\mathrm{b}}$ & $7.15 \pm 0.15$ & $9.27 \pm 0.75$ \\
\hline \multirow[t]{3}{*}{ AGS } & 0 & $1.98 \pm 0.48$ & $63.35 \pm 2.23$ & $13.30 \pm 0.79$ & $31.83 \pm 1.15$ \\
\hline & 1.0 & $2.59 \pm 0.15$ & $68.48 \pm 2.45^{\mathrm{a}}$ & $10.35 \pm 0.42$ & $18.86 \pm 0.28$ \\
\hline & 5.0 & $1.05 \pm 0.04$ & $75.15 \pm 0.99^{b}$ & $7.27 \pm 0.40$ & $16.72 \pm 1.37$ \\
\hline \multirow[t]{3}{*}{ KATO-III } & 0 & $1.27 \pm 0.09$ & $60.32 \pm 0.92$ & $12.79 \pm 0.22$ & $26.09 \pm 1.17$ \\
\hline & 1.0 & $1.12 \pm 0.30$ & $72.72 \pm 0.83^{b}$ & $9.80 \pm 0.56$ & $16.66 \pm 0.04$ \\
\hline & 5.0 & $0.88 \pm 0.01$ & $82.74 \pm 1.64^{b}$ & $5.18 \pm 0.31$ & $11.34 \pm 1.26$ \\
\hline \multirow[t]{3}{*}{ NCI-N87 } & 0 & $0.51 \pm 0.05$ & $65.60 \pm 3.00$ & $10.88 \pm 1.55$ & $22.33 \pm 0.50$ \\
\hline & 1.0 & $0.21 \pm 0.04$ & $75.60 \pm 1.04^{\mathrm{b}}$ & $5.06 \pm 0.07$ & $19.28 \pm 1.09$ \\
\hline & 5.0 & $0.41 \pm 0.06$ & $74.65 \pm 1.57^{\mathrm{a}}$ & $6.27 \pm 0.36$ & $18.90 \pm 1.22$ \\
\hline
\end{tabular}

One-way analysis of variance was used to analyze the data. ${ }^{\mathrm{a}} \mathrm{P}<0.05$; ${ }^{\mathrm{b}} \mathrm{P}<0.001$ compared to treated with $0 \mu \mathrm{M} \mathrm{PD} 0332991$.

A
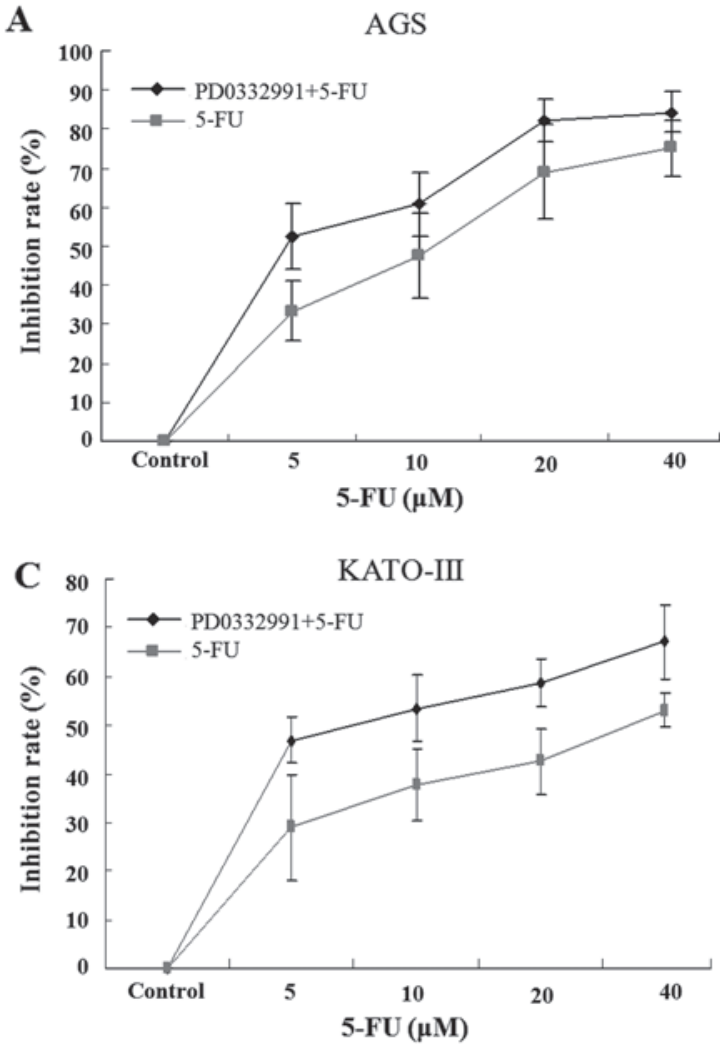

B
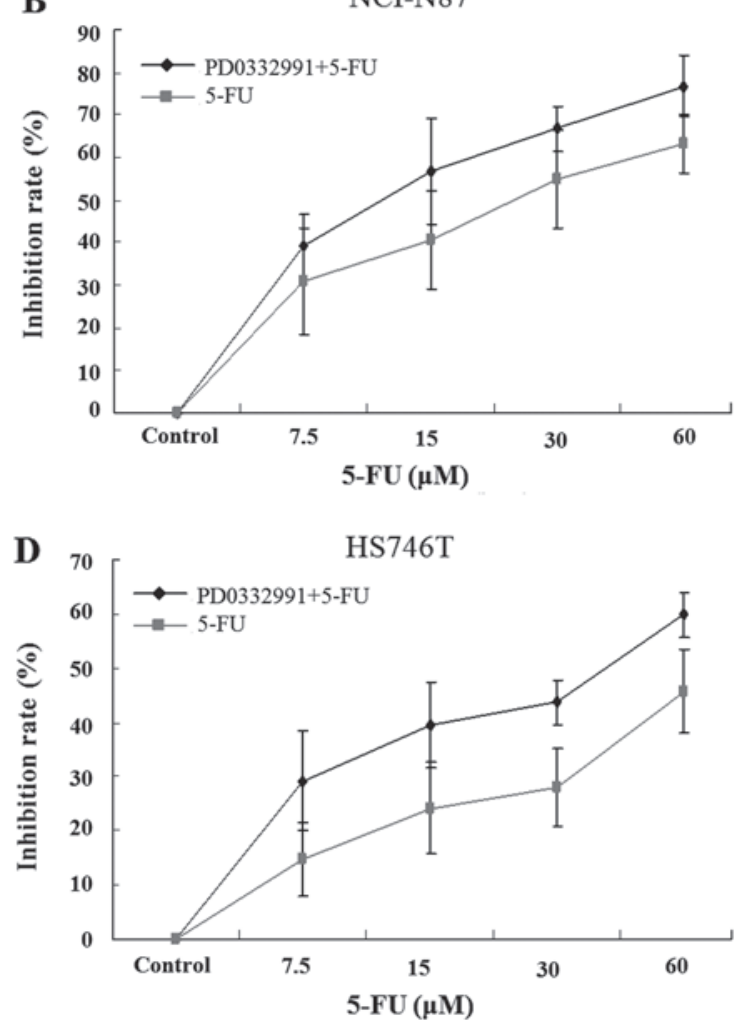

Figure 3. Effects of treatment with 5-FU alone and PD0332991 + 5-FU no (A) AGS, (B) NCI-N87, (C) KATO-III and (D) HS746T cells, as determined by MTT assay. Results are presented as the means \pm standard deviation of three independent experiments performed in triplicate. 5-FU, fluorouracil.

lation of Rb on Ser780 (Fig. 5A). These findings confirmed that PD0332991 may potently inhibit CDK4/6 activity in GC cells.

The present study also investigated the effects of PD0332991 on other proteins involved in $G_{0} / G_{1}$ cell cycle arrest. KATO-III cells were treated with various doses of PD0332991 $(0,0.2,1,5$ and $25 \mu \mathrm{M})$ for $72 \mathrm{~h}$. The ratio of signal intensity for each protein was compared with $\beta$-actin.
As shown in Fig. 5B and C, treatment of KATO-III cells with PD0332991 resulted in a marked decrease in the expression of cyclin D1. In addition, PD0332991 induced the expression of p53 and p27 in GC cells in a dose-dependent manner (Fig. 5B, $\mathrm{D}$ and E). These results suggested that p53 and p27 may be associated with the ability of PD0332991 to induce $G_{0} / G_{1}$ arrest in GC cells. 

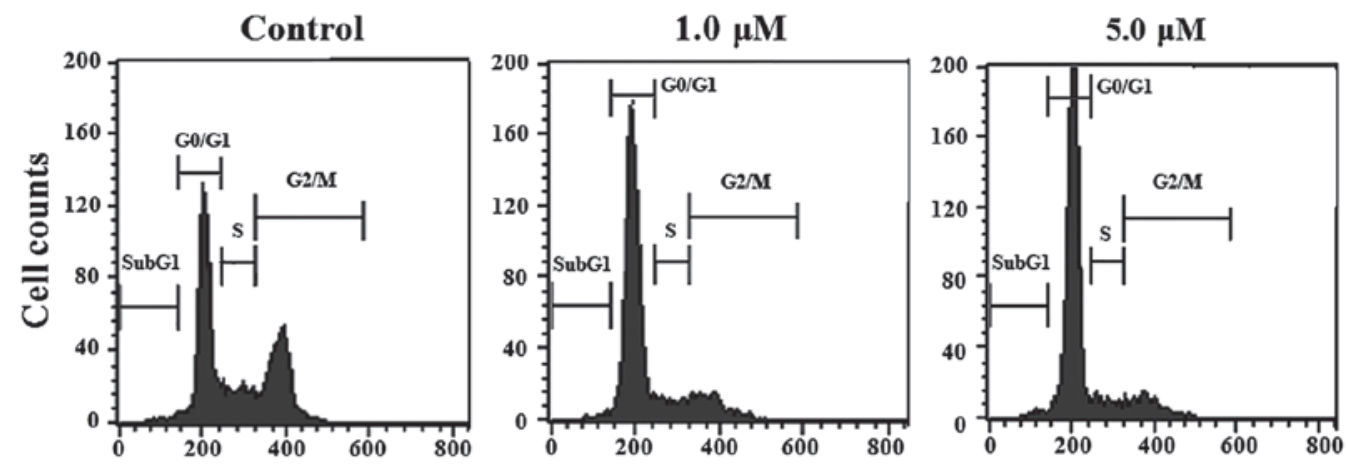

\section{HS746T}
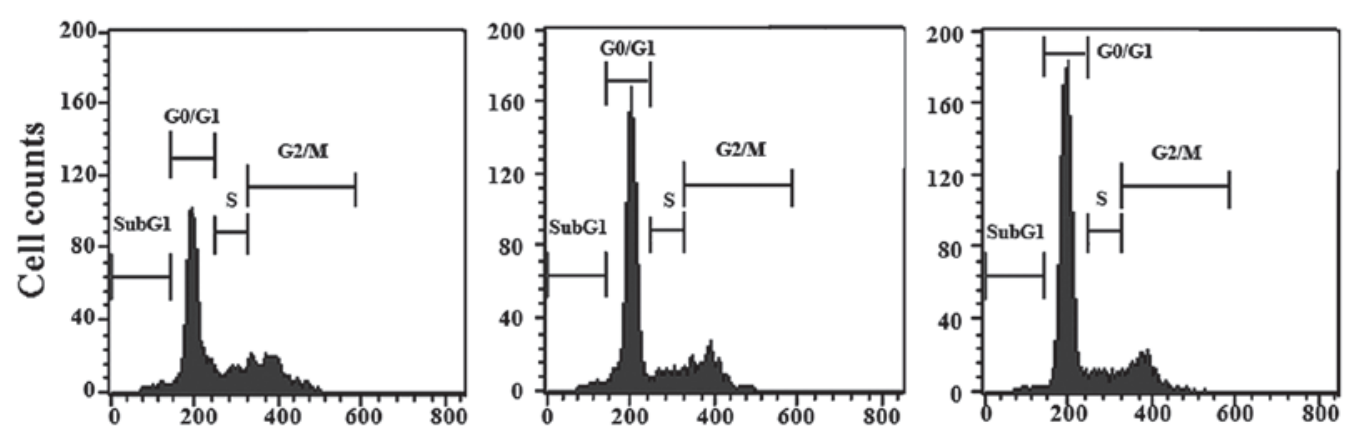

AGS
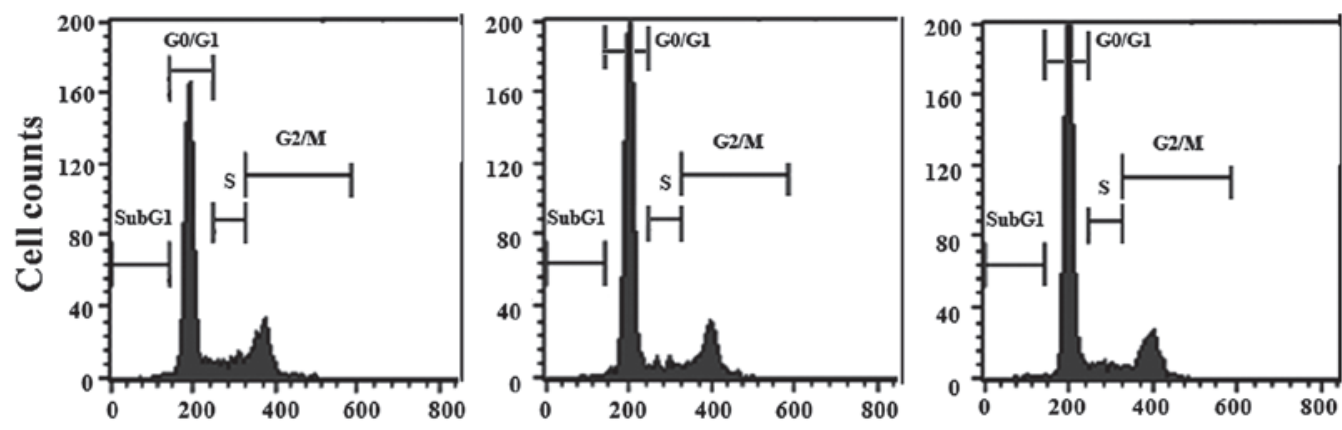

NCI-N87
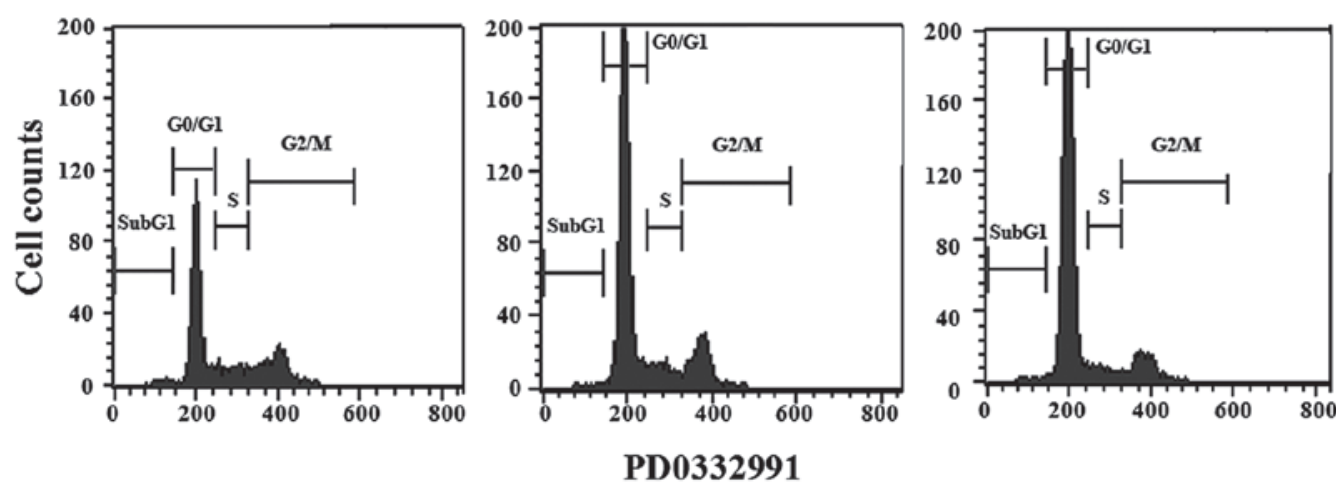

KATO-III

Figure 4. Cell cycle analysis of HS746T, AGS, NCI-N87 and KATO-III cells treated with PD0332991. Cells were treated with various doses of PD0332991 for $72 \mathrm{~h}$. Subsequently, cells were fixed and stained with propidium iodide. Cell cycle distribution was analyzed by flow cytometry. Data from one of three experiments are shown, including flow cytometry plot and summarized data. One-way analysis of variance was used to analyze data. ${ }^{*} \mathrm{P}<0.05 ;{ }^{* *} \mathrm{P}<0.001$.

Effects of PD0332991 on the expression of signaling proteins in GC cells. To further identify the molecular mechanisms by which PD0332991 initiates $G_{0} / G_{1}$ arrest in GC cells, the four GC cell lines were treated with PD0332991 ( $\mathrm{IC}_{75}$ ) for $48 \mathrm{~h}$. Subsequently, protein expression patterns were analyzed using PPA analysis. Proteins that exhibited a $>2$-fold alteration in expression in response to PD0332991 were considered differentially expressed. A total of 43 proteins were revealed to be differentially expressed in AGS cells (Fig. 6A), 32 in KATO-III cells (Fig. 6B), 29 in NCI-N87 cells (Fig. 6C) and 39 in HS746T cells (Fig. 6D). A total of 31 proteins were similarly regulated in at least three cell lines. Pathway analysis identified categories associated with cellular development ( 23 proteins, $\left.\mathrm{P}=1.00 \times 10^{-17}-3.49 \times 10^{-6}\right)$, cell death $\left(23\right.$ proteins, $\left.\mathrm{P}=5.47 \times 10^{-17}-3.25 \times 10^{-6}\right)$, cancer (26 proteins, $\left.\mathrm{P}=7.21 \times 10^{-17}-3.25 \times 10^{-6}\right)$, cell cycle (21 proteins, $\left.\mathrm{P}=7.63 \times 10^{-17}-3.49 \times 10^{-6}\right)$, and cell growth and proliferation (24 proteins, $\mathrm{P}=7.07 \times 10^{-17}-3.25 \times 10^{-3}$ ). Notably, a large number of genes regulating cell proliferation and cell cycle progression were downregulated by PD0332991.

Identification ofbiologicalpathways modulated by PD0332991 in GC cells. The present study further analyzed the PD0332991 
A
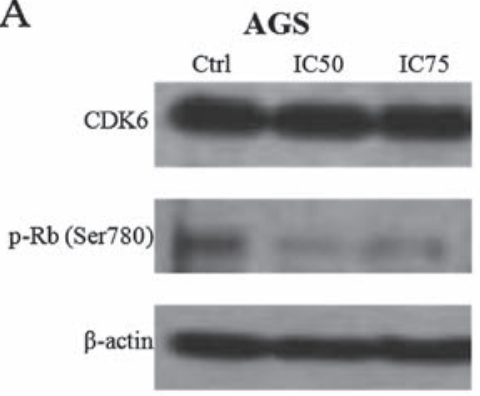

NCI-N87
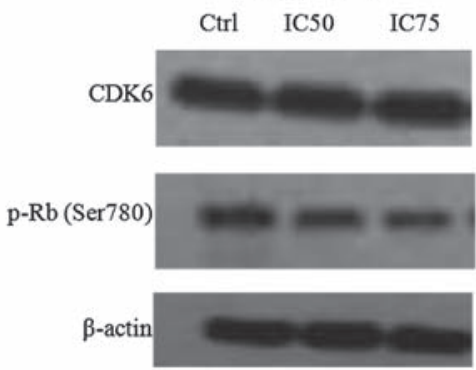

B

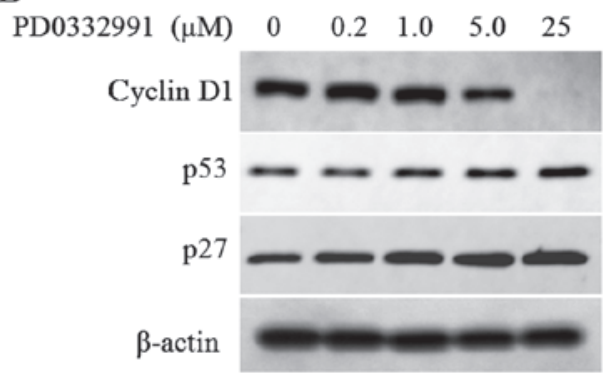

D

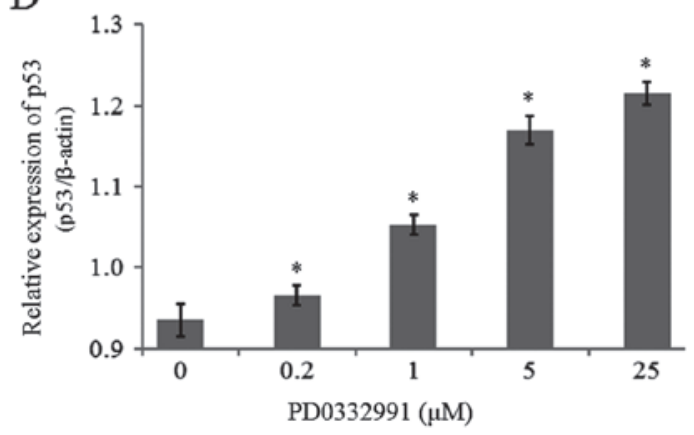

\section{KATO-III}
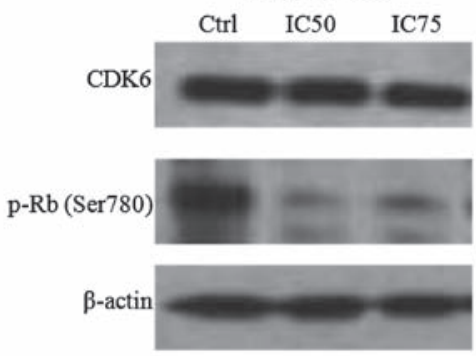

HS746T

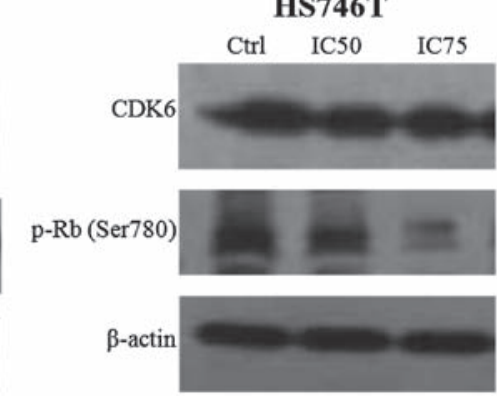

C

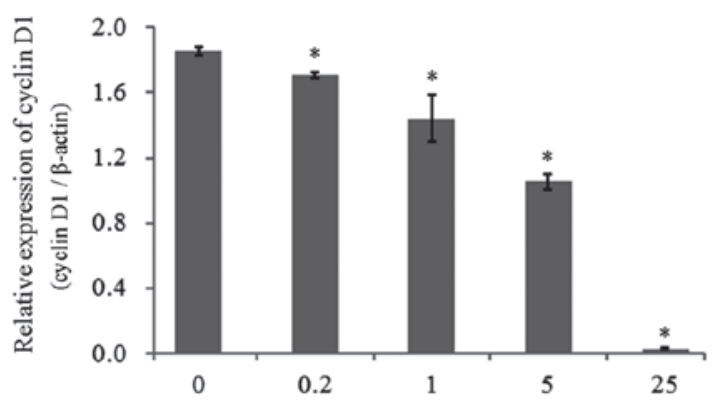

$\mathrm{E}$

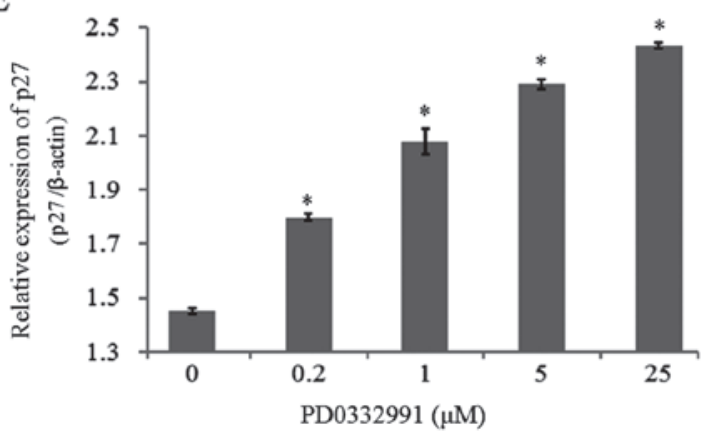

Figure 5. PD0332991 treatment inhibits Rb (Ser780) phosphorylation, downregulates cyclin D1 expression and upregulates the expression of p53 and p27. (A) Cells were treated with various doses of PD0332991 and the levels of CDK6 and p-Rb (Ser780) were examined by immunoblotting. $\beta$-actin was used as a loading control. (B) Cells were treated with various doses of PD0332991 and the protein expression levels of cyclin D1, p53 and p27 were examined by immunoblotting. $\beta$-actin was used as a loading control. (C) Ratio of cyclin D1 to $\beta$-actin was decreased by PD0332991, in a dose-dependent manner. (D) Ratio of p53 to $\beta$-actin was increased by PD0332991, in a dose-dependent manner. (E) Ratio of p27 to $\beta$-actin was increased by PD0332991, in a dose-dependent manner. ${ }^{*} \mathrm{P}<0.05$. CDK6, cyclin-dependent kinase 6; $\mathrm{IC}_{50}, 50 \%$ inhibitory concentration; $\mathrm{IC}_{75}, 75 \%$ inhibitory concentration; p-Rb, phosphorylated-retinoblastoma.

target proteins, in order to determine key biological pathways modulated by PD0332991 treatment. IPA was performed on 31 proteins that were targeted by PD0332991 in GC cell lines. Five networks were revealed to be altered by PD0332991. The top three networks were mainly associated with cell death, cell cycle and molecular mechanism of cancer (Fig. 7). The results of IPA also indicated that PD0332991 target proteins are involved in numerous canonical signaling pathways, including molecular mechanisms of cancer $\left(\mathrm{P}=6.06 \times 10^{-17}\right)$, p53 signaling $\left(\mathrm{P}=1.46 \times 10^{-11}\right)$, phosphatidylinositol 3-kinase $(\mathrm{PI} 3 \mathrm{~K}) /$ protein kinase $\mathrm{B}$ (PKB) (PI3K/AKT) signaling $\left(\mathrm{P}=1.07 \times 10^{-10}\right)$, apoptosis signaling $\left(\mathrm{P}=4.58 \times 10^{-10}\right)$, phosphatase and tensin homolog signaling $\left(\mathrm{P}=3.55 \times 10^{-8}\right), 14-3-3$-mediated signaling $\left(\mathrm{p}=1.14 \times 10^{-7}\right)$, Janus kinase/signal transducer and activator of transcription signaling $\left(P=2.04 \times 10^{-7}\right)$, cell cycle: $G_{2} / M$ DNA damage checkpoint regulation $\left(\mathrm{P}=1.52 \times 10^{-6}\right)$, epidermal 

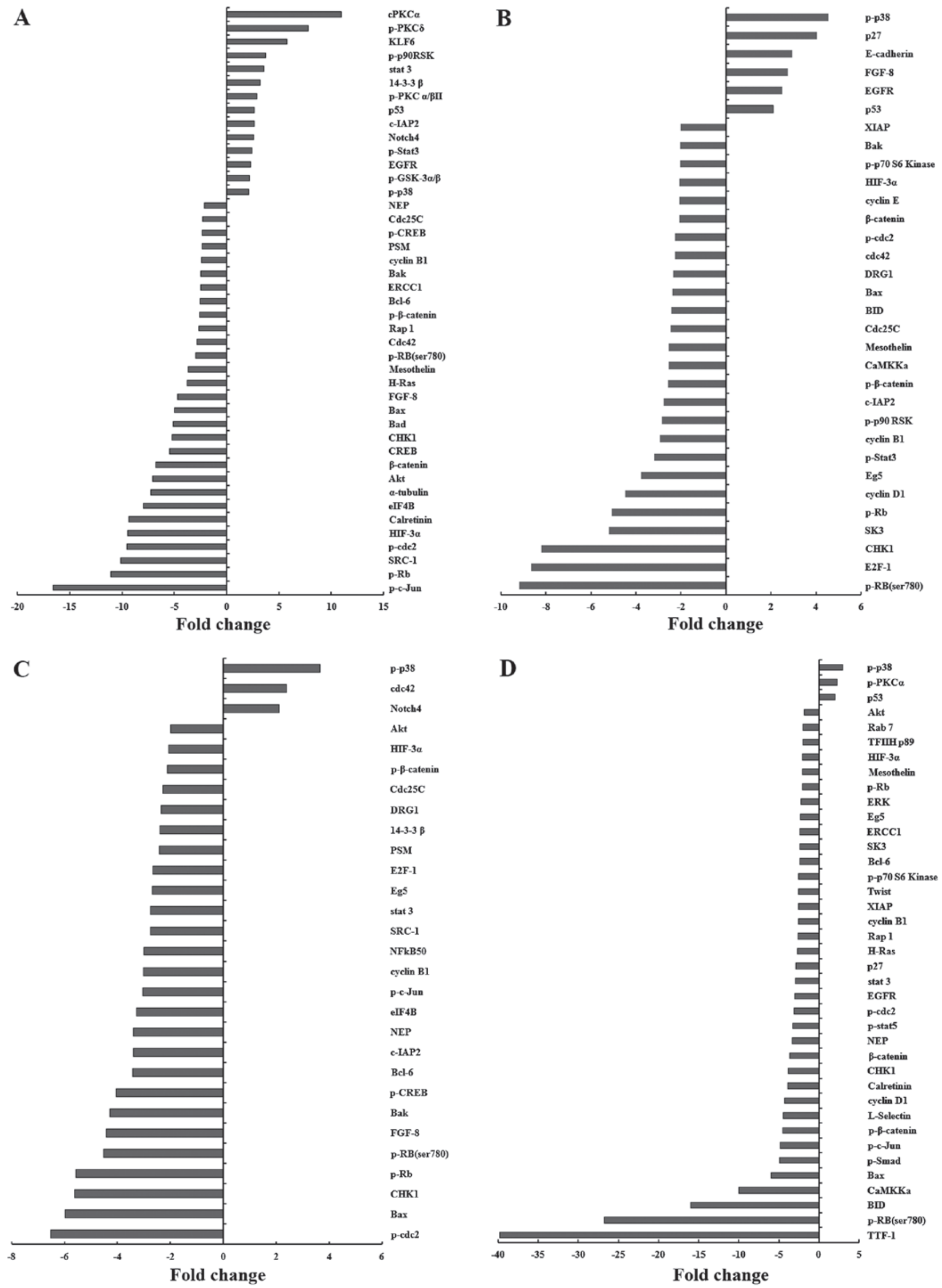

Figure 6. Identification of altered proteins using protein pathway array following treatment with PD0332991. (A) A total of 43 proteins were differentially expressed in AGS cells, (B) 32 in KATO-III cells, (C) 29 in NCI-N87 cells and (D) 39 in HS746T cells. 

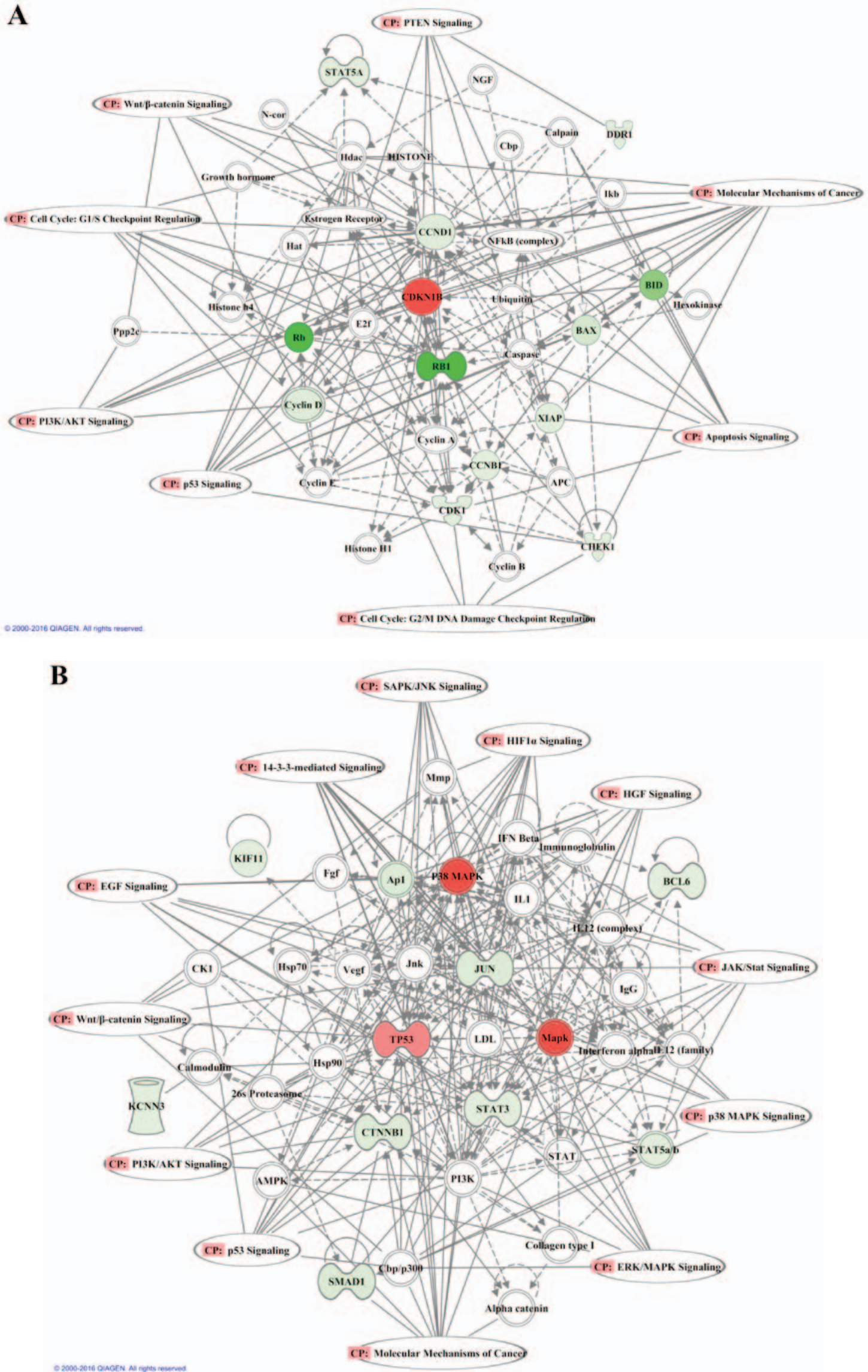

Figure 7. Identification of PD0332991-regulated gastric cancer cell signaling networks. The top three networks identified by Ingenuity Pathway Analysis from up- and downregulated proteins were associated with cell death, cell cycle and molecular mechanism of cancer network. The network is displayed graphically as nodes (proteins) and edges (the biological association between the nodes). Overexpressed proteins (PD0332991 compared with control) are shaded in red, and downregulated proteins are shaded in green; darker shading indicate a strong difference. The various-shaped nodes represent the functional class of the proteins. Canonical pathways with high scores, which are associated with these proteins, are also presented. (A) The network with the highest score; (B) the network with the second highest score. 


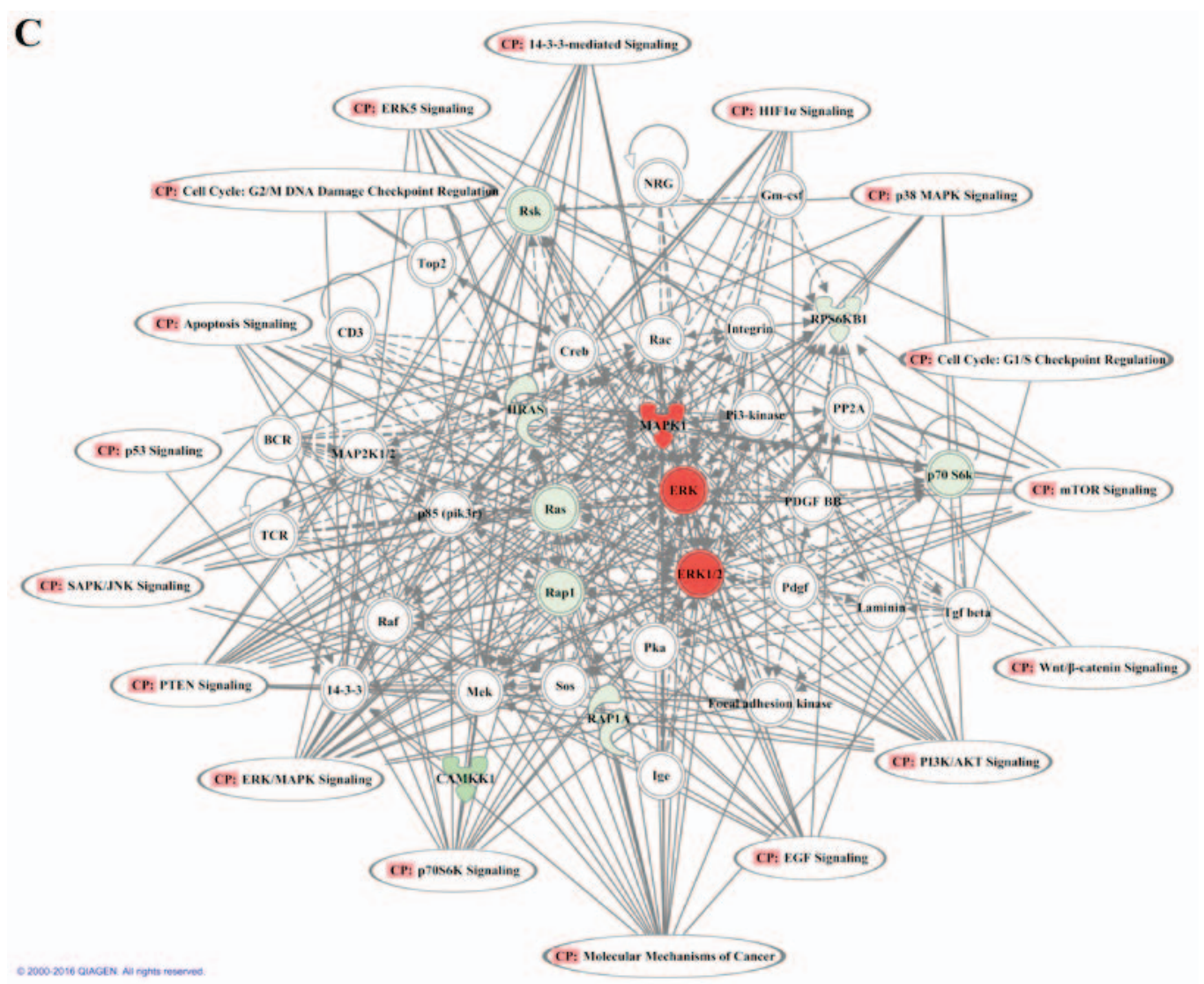

Figure 7. Continued. Identification of PD0332991-regulated gastric cancer cell signaling network. The top three networks identified by Ingenuity Pathway Analysis from up- and downregulated proteins were associated with cell death, cell cycle and molecular mechanism of cancer network. The network is displayed graphically as nodes (proteins) and edges (the biological association between the nodes). Various overexpressed proteins (PD0332991 compared with control) are shaded in red, and various downregulated proteins are shaded in green; darker shading indicates a strong difference. The various-shaped nodes represent the functional class of the proteins. Canonical pathways with high scores, which are associated with these proteins, are also presented. (C) The network with the third highest score.

growth factor signaling $\left(\mathrm{P}=2.26 \times 10^{-6}\right)$, hypoxia-inducible factor $1 \alpha$ signaling $\left(P=2.44 \times 10^{-6}\right)$, cell cycle: $\mathrm{G}_{1} / \mathrm{S}$ checkpoint regulation $\left(\mathrm{P}=5.7 \times 10^{-6}\right)$, fibroblast growth factor signaling $\left(\mathrm{P}=3.02 \times 10^{-5}\right)$, Rac signaling $\left(\mathrm{P}=7.11 \times 10^{-5}\right)$, p70S6 kinase signaling $\left(\mathrm{P}=1.30 \times 10^{-4}\right)$, mammalian target of rapamycin signaling $\left(\mathrm{P}=2.05 \times 10^{-4}\right)$, extracellular signal-regulated protein kinase $(\mathrm{ERK}) 5$ signaling $\left(\mathrm{P}=4.25 \times 10^{-4}\right)$, retinoic acid receptor activation $(\mathrm{P}=4.32 \mathrm{X} 10-4), \mathrm{Wnt} / \beta$-catenin signaling $\left(\mathrm{P}=4.42 \times 10^{-4}\right), \mathrm{ERK} / \mathrm{mitogen}$-activated protein kinase (MAPK) signaling $\left(\mathrm{P}=5.65 \times 10^{-4}\right)$, and stress-activated protein kinase/c-Jun $\mathrm{N}$-terminal kinase $(\mathrm{JNK})$ signaling $\left(\mathrm{P}=1.01 \times 10^{-3}\right)$ (Fig. 7).

\section{Discussion}

PD0332991, a pyrido[2,3- $d$ ]pyrimidin-7-one inhibitor, is a selective inhibitor of CDK4 and CDK6 (6) that has been reported to inhibit the growth of a panel of Rb-positive solid tumor cell lines (5,7). Recently, PD0332991 was approved by the FDA to treat advanced breast cancer. The present study demonstrated that PD0332991 exerts potent antiproliferative activity in human GC cells. Consistent with the established role of CDK4/6 in cell cycle progression, PD0332991 induced $\mathrm{G}_{0} / \mathrm{G}_{1}$ arrest, and reduced phosphorylation of $\mathrm{Rb}$ at the CDK4/6-specific Ser780 site. Accordingly, the levels of cyclin D1 were decreased, whereas the expression levels of p27 were increased following treatment with PD0332991.

The combination of targeted therapeutic agents with cytotoxic chemotherapy has become a standard therapeutic strategy for the treatment of numerous types of cancer. 5-FU is a major chemotherapy drug used to treat GC. In the present study, cells were cotreated with PD0332991 and 5-FU; the results demonstrated that PD0332991 increased the cytotoxic effects of 5-FU on all four GC cell lines.

Using large scale proteomic analysis, the present study identified numerous proteins that were altered in GC cells upon treatment with PD0332991. Data analysis demonstrated that PD0332991 altered the expression of proteins involved in the regulation of cellular development, cell death, cell cycle, cell growth and proliferation, and cell migration. Proteins regulated by PD0332991 were involved in several canonical pathways, including molecular mechanism of cancer, p53 signaling and PI3K/AKT signaling, Ras-ERK pathway, JNK/MAPK pathway, Wnt/ß-catenin pathway and Smad signaling (Fig. 7).

c-Jun is a transcription factor, which serves a role in the development of skin and liver tumors $(18,19)$. c-Jun is a positive regulator of cell proliferation, and c-Jun-deficient fibroblasts exhibited marked defects in proliferation in vitro (20-22). In addition, the proliferation of c-Jun-deficient hepatocytes is severely impaired during liver regeneration in vivo (20). The c-Jun protein is acti- 
vated by JNKs (23). Subsequently, the activated c-Jun-containing activator protein-1 complex induces transcription of positive regulators of cell cycle progression, including cyclin D1, or suppresses negative regulators, including the tumor suppressor p53 and the CDK inhibitor INK4A. c-Jun can also cooperate with activated Ras (24). The present study demonstrated that following treatment with PD0332991, H-Ras, p-c-Jun and cyclin D1 were downregulated, whereas p53 was upregulated in GC cells. These alterations suggested that the Ras/Jun pathway may participate in PD0332991-induced growth inhibition and cell cycle arrest.

Hyperactivation of the Wnt/ $\beta$-catenin pathway may lead to aberrant cell growth (25) in various types of cancer. The present study demonstrated that the expression levels of p-catenin and unphosphorylated-catenin were decreased in GC cell lines following treatment with PD0332991. Consistent with this finding, the expression levels of cyclin D1, a target of Wnt signaling, were also inhibited by PD0332991, thus suggesting that PD0332991 may inhibit growth of GC cells by inhibiting Wnt $/ \beta$-catenin signaling. Furthermore, the expression levels of $\mathrm{p}$-Smad were decreased in GC cells following treatment with PD0332991, which may also contribute to the growth inhibition of GC cells.

The transcription factor p53 is a critical component in the normal cell response to cellular stress, including DNA damage, oncogenic stimulation, nutrient deprivation or hypoxia (26). Its role as a tumor suppressor is exemplified by the fact that numerous types of cancer are associated with selective inactivation of p53 and/or p53 pathways. p53 serves a critical role during the DNA damage-induced $\mathrm{G}_{1} / \mathrm{S}$ cell cycle checkpoint; p53-deficient cells fail to undergo $G_{1} / S$ arrest in response to genotoxic stress (27-29). The present study demonstrated that PD0332991 induced p53 expression, which may underlie the ability of PD0332991 to induce $\mathrm{G}_{1} / \mathrm{S}$ arrest in GC cells.

AKT protects cells from apoptosis by phosphorylating downstream target proteins involved in the regulation of cell growth and survival, including glycogen synthase kinase- $3 \beta$, p21, p27, X-linked inhibitor of apoptosis protein, B-cell lymphoma 2-associated death promoter and forkhead box $\mathrm{O} 3 \alpha$ (30). Suppression of AKT activity has been reported to lead to p53 activation, which in turn may lead to growth arrest and activation of proapoptotic signaling pathways (31). The present study indicated that following treatment with PD0332991, AKT was downregulated, and p53 and p27 were upregulated, thus suggesting that the PI3K/AKT pathway may have an important role in the effects of PD0332991 on GC cells.

In conclusion, the present study demonstrated that PD0332991 inhibits cell proliferation via modulation of cell cycle progression, and that numerous signaling pathways are regulated by PD0332991. These results suggested that PD0332991 may be considered a promising preventive and therapeutic agent for the treatment of GC.

\section{Acknowledgements}

The present study was supported by National Natural Science Foundation of China grants (grant nos. 81372295 and 81402374).

\section{Competing interests}

The authors declare that they have no competing interests.

\section{References}

1. Carcas LP: Gastric cancer review. J Carcinog 13: 14, 2014.

2. Thiel A and Ristimäki A: Targeted therapy in gastric cancer. APMIS 123: 365-372, 2015.

3. Hohenberger P and Gretschel S: Gastric cancer. Lancet 362: 305-315, 2003

4. May P and May E: Twenty years of p53 research: Structural and functional aspects of the p53 protein. Oncogene 18: 7621-7636, 1999.

5. Fry DW, Harvey PJ, Keller PR, Elliott WL, Meade M, Trachet E, Albassam M, Zheng X, Leopold WR, Pryer NK, et al: Specific inhibition of cyclin-dependent kinase $4 / 6$ by PD0332991 and associated antitumor activity in human tumor xenografts. Mol Cancer Ther 3: 1427-1438, 2004.

6. Toogood PL, Harvey PJ, Repine JT, Sheehan DJ, VanderWel SN, Zhou H, Keller PR, McNamara DJ, Sherry $\mathrm{D}$, Zhu T, et al: Discovery of a potent and selective inhibitor of cyclin-dependent kinase 4/6. J Med Chem 48: 2388-2406, 2005.

7. VanderWel SN, Harvey PJ, McNamara DJ, Repine JT, Keller PR, Quin J III, Booth RJ, Elliott WL, Dobrusin EM, Fry DW, et al: Pyrido[2,3-d]pyrimidin-7-ones as specific inhibitors of cyclin-dependent kinase 4. J Med Chem 48: 2371-2387, 2005.

8. Foo $\mathrm{M}$ and Leong T: Adjuvant therapy for gastric cancer: Current and future directions. World J Gastroenterol 20: 13718-13727, 2014.

9. Kanat $\mathrm{O}$ and $\mathrm{O}^{\prime} \mathrm{Neil} \mathrm{BH}$ : Metastatic gastric cancer treatment: A little slow but worthy progress. Med Oncol 30: 464, 2013.

10. Sherr CJ and Roberts JM: CDK inhibitors: Positive and negative regulators of G1-phase progression. Genes Dev 13: 1501-1512, 1999.

11. Lee SR, Shin JW, Kim HO, Son BH, Yoo CH and Shin JH: Determining the effect of transforming growth factor- $\beta 1$ on cdk4 and p27 in gastric cancer and cholangiocarcinoma. Oncol Lett 5: 694-698, 2013.

12. Motohashi M, Wakui S, Muto T, Suzuki Y, Shirai M, Takahashi $\mathrm{H}$ and Hano $\mathrm{H}$ : Cyclin D1/cdk4, estrogen receptors $\alpha$ and $\beta$, in N-methyl-N'-nitro-N-nitrosoguanidine-induced rat gastric carcinogenesis: Immunohistochemical study. J Toxicol Sci 36: 373-378, 2011.

13. Takano Y, Kato Y, van Diest PJ, Masuda M, Mitomi H and Okayasu I: Cyclin D2 overexpression and lack of p27 correlate positively and cyclin E inversely with a poor prognosis in gastric cancer cases. Am J Pathol 156: 585-594, 2000.

14. Dhillon S: Palbociclib: First global approval. Drugs 75: 543-551, 2015.

15. Carey LA and Perou CM: Palbociclib - taking breast-cancer cells out of gear. N Engl J Med 373: 273-274, 2015.

16. Dukelow T, Kishan D, Khasraw M and Murphy CG: CDK4/6 inhibitors in breast cancer. Anticancer Drugs 26: 797-806, 2015.

17. Morikawa A and Henry NL: Palbociclib for the treatment of estrogen receptor-positive, HER2-negative metastatic breast cancer. Clin Cancer Res 21: 3591-3596, 2015.

18. Young MR, Li JJ, Rincón M, Flavell RA, Sathyanarayana BK, Hunziker R and Colburn N: Transgenic mice demonstrate AP-1 (activator protein-1) transactivation is required for tumor promotion. Proc Natl Acad Sci USA 96: 9827-9832, 1999.

19. Eferl R, Ricci R, Kenner L, Zenz R, David JP, Rath M and Wagner EF: Liver tumor development. c-Jun antagonizes the proapoptotic activity of p53. Cell 112: 181-192, 2003.

20. Behrens A, Sibilia M, David JP, Möhle-Steinlein U, Tronche F, Schütz G and Wagner EF: Impaired postnatal hepatocyte proliferation and liver regeneration in mice lacking c-jun in the liver. EMBO J 21: 1782-1790, 2002.

21. Schreiber M, Kolbus A, Piu F, Szabowski A, Möhle-Steinlein U, Tian J, Karin M, Angel P and Wagner EF: Control of cell cycle progression by c-Jun is p53 dependent. Genes Dev 13: 607-619, 1999.

22. Wisdom R, Johnson RS and Moore C: c-Jun regulates cell cycle progression and apoptosis by distinct mechanisms. EMBO J 18: 188-197, 1999.

23. Behrens A, Sibilia M and Wagner EF: Amino-terminal phosphorylation of c-Jun regulates stress-induced apoptosis and cellular proliferation. Nat Genet 21: 326-329, 1999.

24. Mechta F, Lallemand D, Pfarr CM and Yaniv M: Transformation by ras modifies AP1 composition and activity. Oncogene 14: 837-847, 1997. 
25. Reya T and Clevers $\mathrm{H}$ : Wnt signalling in stem cells and cancer. Nature 434: 843-850, 2005.

26. Amelio I and Melino G: The p53 family and the hypoxia-inducible factors (HIFs): Determinants of cancer progression. Trends Biochem Sci 40: 425-434, 2015.

27. Baker SJ, Markowitz S, Fearon ER, Willson JK and Vogelstein B: Suppression of human colorectal carcinoma cell growth by wild-type p53. Science 249: 912-915, 1990.

28. Diller L, Kassel J, Nelson CE, Gryka MA, Litwak G, Gebhardt M, Bressac B, Ozturk M, Baker SJ and Vogelstein B: p53 functions as a cell cycle control protein in osteosarcomas. Mol Cell Biol 10: 5772-5781, 1990

29. Martinez J, Georgoff I, Martinez J and Levine AJ: Cellular localization and cell cycle regulation by a temperature-sensitive p53 protein. Genes Dev 5: 151-159, 1991 .
30. Steelman LS, Stadelman KM, Chappell WH, Horn S, Bäsecke J, Cervello M, Nicoletti F, Libra M, Stivala F, Martelli AM, et al: Akt as a therapeutic target in cancer. Expert Opin Ther Targets 12: 1139-1165, 2008.

31. Fraser M, Leung BM, Yan X, Dan HC, Cheng JQ and Tsang BK: p53 is a determinant of X-linked inhibitor of apoptosis protein/Akt-mediated chemoresistance in human ovarian cancer cells. Cancer Res 63: 7081-7088, 2003.

This work is licensed under a Creative Commons Attribution-NonCommercial-NoDerivatives 4.0 International (CC BY-NC-ND 4.0) License. 